\title{
Sustainability Strategies for Regional Health Information Organization Startups
}

Winkler, Till J.; Ozturk, Pinar; Brown, Carol V.

\author{
Document Version \\ Accepted author manuscript \\ Published in: \\ Health Policy and Technology \\ DOI: \\ 10.1016/j.hlpt.2016.07.002 \\ Publication date: \\ 2016 \\ License \\ CC BY-NC-ND
}

Citation for published version (APA):

Winkler, T. J., Ozturk, P., \& Brown, C. V. (2016). Sustainability Strategies for Regional Health Information

Organization Startups. Health Policy and Technology, 5(4), 341-349. https://doi.org/10.1016/j.hlpt.2016.07.002

Link to publication in CBS Research Portal

\section{General rights}

Copyright and moral rights for the publications made accessible in the public portal are retained by the authors and/or other copyright owners and it is a condition of accessing publications that users recognise and abide by the legal requirements associated with these rights.

\section{Take down policy}

If you believe that this document breaches copyright please contact us (research.lib@cbs.dk) providing details, and we will remove access to the work immediately and investigate your claim.

Download date: 26. Apr. 2023
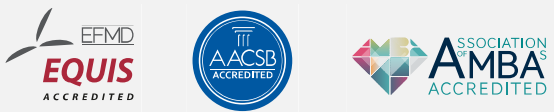


\title{
Sustainability Strategies for Regional Health Information Organization Startups
}

\author{
Till J. Winkler, Pinar Ozturk, and Garol V. Brown
}

Journal article (Post print version)

Cite: Sustainability Strategies for Regional Health Information Organization Startups. / Winkler, Till J.; Ozturk, Pinar; Brown, Carol V. In: Health Policy and Technology, 11.07.2016.

DOI: 10.1016/j.hlpt.2016.07.002

Uploaded to Research@CBS: September २०16

(1) 2016. This manuscript version is made available under the CC-BY-NC-ND 4.0 license

http://creativecommons.org/licenses/by-nc-nd/4.0/ 


\title{
Sustainability Strategies for Regional Health Information Organization Startups
}

\author{
Till J. Winkler, Dr. \\ Assistant Professor \\ Department of IT Management \\ Copenhagen Business School \\ 2000 Frederiksberg, Denmark \\ Email: tw.itm@cbs.dk \\ Pinar Ozturk, M.Sc. \\ $\mathrm{PhD}$ candidate \\ School of Business \\ Stevens Institute of Technology \\ Hoboken, New Jersey 07030 \\ Email: pozturk@stevens.edu \\ Carol V. Brown, Ph.D. \\ Distinguished Service Professor (emerita) \\ School of Business \\ Stevens Institute of Technology \\ Hoboken, New Jersey 07030 \\ Email: carol.brown@stevens.edu
}

\section{Accepted manuscript version (pre-print)}

\section{Cite as}

Winkler, Till J., Pinar Ozturk and Carol V. Brown. "Sustainability Strategies for Regional Health Information Organization Startups". Health Policy and Technology. Published online July 11 2016. Available: $\underline{10.1016 / \text { j.hlpt.2016.07.002 }}$

\section{Highlights}

- The U.S. HITECH Act was a catalyst for health information organizations (HIOs).

- This article identifies key characteristics of sustainable regional HIO startups.

- Two viable models are proposed for urban versus suburban populations.

- Future HIO research needs to account for regional context differences. 


\title{
Sustainability Strategies for Regional Health Information Organization Startups
}

\begin{abstract}
Objectives: Similar to other Western healthcare systems, the U.S. has sought to build a national infrastructure to enable widespread electronic health information exchange (HIE). The 2009 U.S. HITECH Act's State HIE Cooperative Agreement Program (SHIECAP) was a short-term catalyst for bottom-up HIE initiatives by states and regional health information organizations (HIOs). Given the high failure rates of regional U.S. HIOs in the past, our primary objective is to identify the key characteristics of HIO startups that became operational and demonstrated sustainability with non-renewable SHIECAP funding in a state environment with very minimal prior HIE activities.

Methods: Based on interview data we collected from 22 stakeholders in New Jersey (NJ) at the state, HIO, and hospital levels, we apply grounded theory techniques to identify cross-case similarities and differences.

Results: Although the three NJ HIOs that became operational during the SHIECAP grant period faced similar startup challenges, the two HIOs that demonstrated sustainability pursued distinct technology and sustainability strategies to develop HIE capabilities to fit their very different regional needs: an HIE capability to improve the population health of an underserved urban population, and an HIE capability to enable the transition to a healthcare landscape that rewards care coordination across suburban hospitals and physician practices.

Conclusions: We propose two models of technology and sustainability strategies for developing bottom-up HIE capabilities for different regional populations. Future research within and beyond U.S. contexts needs to take into account these key characteristics to improve our understanding of effective policy levers and government funding mechanisms.
\end{abstract}

Key Words: Health information exchange, Health information organization, U.S. HITECH Act, Technology strategies, Financial sustainability, Regional context. 


\section{Sustainability Strategies for HIO Startups}

\section{INTRODUCTION}

Electronic health information exchange (HIE) across multiple healthcare settings has been recognized as key to addressing the cost, quality and accessibility challenges of national healthcare systems by enabling a capability that 'lets health data follow the patient' [1,2]. Although the governments of most Western industrialized countries have made immense investments into implementing national HIE infrastructures, these initiatives have attained varying levels of success [3, 4]. In the U.S., for example, different top-down funding mechanisms and bottom-up organizational initiatives have been underway for more than two decades. However, less than half [5] of HIE initiatives in the U.S. in the 1990s reported attaining operational sustainability, and high defunct rates continued to be reported in the following decade [6] due to not only funding challenges, but also a lack of U.S. standards for exchanging health information, security issues, and concerns about economic loss to competitors [7]. The startup funding for regional health information organizations (HIOs) received from federal and state governments and other sources was no guarantee of financial viability [8].

Most recently, the U.S. Health Information Technology for Economic and Clinical Health (HITECH) Act, signed into law in February 2009, has been a major catalyst for investments to enable interoperable HIE technologies to link healthcare providers within defined geographical regions [1, 9]. In addition to the $\$ 31$ billion for Meaningful Use (MU) incentive payments to eligible hospitals and physician practices for the implementation of electronic health record (EHR) technologies, the HITECH Act allocated \$564 million to fifty-six U.S. states, eligible territories, and state designated entities under the State HIE Cooperative Agreement Program (SHIECAP) to develop HIE capabilities at the state and regional levels [10]. By 2013 about $30 \%$ of hospital providers and $10 \%$ of ambulatory practices reported participating in one or more HIE entities, versus $14 \%$ of hospital providers and $3 \%$ of ambulatory practices reporting participation in 2010 [11].

Despite this unprecedented public investment and significant uptake in HIE capabilities within the U.S., the quest for sustainable models and long-term viability remain persistent regional HIO concerns $[1,11,12]$. The governmentfunded evaluations of the SHIECAP program [13-16] have focused on state-level achievements and thus have not contributed to our understanding of the key characteristics of HIO models with demonstrated sustainability, especially in states that had no significant HIE capability prior to receiving the SHIECAP funding. Given the unique opportunity to study regional HIOs that first became operational within the same non-renewable, fixed multi-year 


\section{Sustainability Strategies for HIO Startups}

grant period, we therefore embarked on a study that would contribute to our knowledge about the key characteristics associated with successfully developing bottom-up HIE capabilities by addressing the following research question: How and why do HIO startups achieve a financially sustainable, operational model?

To address our research question, we focused on HIO startups within the state of New Jersey (NJ): a populous state with 8.8 million residents that—in comparison to many other U.S. states (e.g., New York [9, 17])—had very limited HIE activities prior to receiving initial funding under the SHIECAP program. We viewed this state-level case setting as a revelatory one [18]: with relatively small funding (\$11.4 million) under the federal SHIECAP program and no additional state-level funding, three HIOs were founded and achieved a high level of operational status within a three-year period (by July 2013). After presenting our qualitative research methods and findings on five common challenges faced by all three of the HIO startups that became operational, we present our findings on the key characteristics of the two HIO startups that provided evidence of financial sustainability for two very different regional contexts: one focused on population health goals for an underserved urban population, and one focused on repositioning suburban hospitals for a healthcare landscape that rewards care coordination.

\section{METHODS}

\section{Data Sources}

The data presented in this paper is primarily based on interview data we collected in June and July 2013. A total of 22 HIE stakeholders in New Jersey were interviewed: state administrators (3), representatives of other state-level entities (3), HIO directors (4), HIO managers (4), hospital CIOs (4), and other hospital staff (4). Each of the three operational HIO startups was represented by the HIO director and at least one other interviewee.

The interviews were conducted by two of the co-authors using position-specific, semi-structured interview guides, which included questions about HIO characteristics reported in prior research (e.g., HIO members, use cases, governance, business model, privacy, technological architecture, vendor, and sustainability dimensions). Each interview typically took place at the interviewee's work site, and lasted between 45 and 60 minutes. All interviews were audio recorded with participant consent and subsequently transcribed. Relevant national, state-level, and HIOlevel archival documents were also collected, as available, from the interviewees as well as from public sources. 


\section{Sustainability Strategies for HIO Startups}

\section{Analysis}

A deductive-inductive qualitative research approach applying grounded theory techniques [19] was used to analyze our interview data. The coding of each transcript was initially performed independently by a pair of researchers using seed categories and sub-categories based on our interview guides and a software package for qualitative analyses (Atlas.ti v.7). These codings were then compared to resolve discrepancies, and the initial codings were modified and expanded on in an iterative process that involved all three researchers over a multi-week period.

A case narrative for each of the three HIO startups that achieved operational status was then developed using a similar heading structure. The primary contact for each HIO was then asked to review the relevant narrative and provide us with feedback on its accuracy and completeness, and this process resulted in a few revisions or additions. A historical state-level narrative was also developed and shared with relevant administrators, with a similar feedback process. Next we focused on identifying the common startup challenges based on cross-case analyses, and then we focused on identifying the key factors that distinguished the two HIOs that had achieved a sustainable startup model (defined as having reached stage 6 or higher in a model by the eHealth initiative [20]), based on the assessments provided by the interviewees. After gaining consent for the inclusion of specific quotations from relevant individuals, we also shared an earlier version of this paper with all primary contacts.

\section{Case Summaries}

\section{New Jersey State Context}

In March 2010, the State of New Jersey, a populous state with no federally-designated rural areas, received a SHIECAP award (\$11.4 million) for the planning and development of four HIO startups and a statewide hub. The four proposed HIO startups included in the NJ proposal for the federal SHIECAP funding under the HITECH Act are described in Table 1.

According to a national taxonomy [21], the proposed leadership role for the state of $\mathrm{NJ}$ was a hybrid: an Orchestrator role in which a thin-layer state-level network connects existing sub-state exchanges, and a CapacityBuilder role to bolster the sub-state exchanges with "financial and technical support, tied to performance goals, with an existing statewide exchange entity." Although two years earlier the state of NJ had allocated funds for an HIT Commission to begin state-level planning, at the time of the SHIECAP award only a few health systems in the state with innovative IT leadership had begun to independently invest in an HIE capability in collaboration with different 
Table 1. Four Proposed New Jersey HIO Startups for SHIECAP Grant

\begin{tabular}{|c|c|c|c|c|}
\hline Characteristics & $\begin{array}{l}\text { Camden Coalition } \\
\text { (CCHP) }\end{array}$ & $\begin{array}{l}\text { Health-e-cITi } \\
\text { (HeC) }\end{array}$ & $\begin{array}{l}\text { Jersey Health } \\
\text { Connect (JHC) }\end{array}$ & $\begin{array}{l}\text { South Jersey } \\
\text { (SJHIE) }\end{array}$ \\
\hline Primary patient population & Urban & Urban & Suburban & Suburban \\
\hline SHIECAP grant & \$1 million & $\$ 3.6$ million & $\$ 3.4$ million & $\$ 1$ million \\
\hline $\begin{array}{l}\text { Founding members of } \\
\text { non-profit }(501 \mathrm{c} 3) \\
\text { organizations }\end{array}$ & $\begin{array}{l}3 \text { hospitals }(+2 \\
\text { Federally Qualified } \\
\text { Health Centers } \\
\text { (FQHCs), } 2 \text { other } \\
\text { providers) }\end{array}$ & $\begin{array}{l}8 \text { hospitals }^{1} \\
(+1 \text { large } \\
\text { physician practice, } \\
1 \text { other provider) }\end{array}$ & $\begin{array}{l}11 \text { hospitals (+2 } \\
\text { nursing homes) }\end{array}$ & 4 hospitals \\
\hline
\end{tabular}

${ }^{1}$ The grant proposal included 8 hospitals, but only 7 of the hospitals became founding members.

vendors. In July 2010, a new Office of HIT Coordinator position within the NJ Governor's office was established to oversee the federally funded HIE initiative (as well as a state-level Regional Extension Center to support the HITECH EHR adoption initiative) for a 3-year period. In comparison to many other states[22], the NJ approach was a minimal intervention model: there were no state-legislated HIE-related mandates and no state-level funds were allocated to the four proposed HIO startups.

By July 2013, the final planning and development of a statewide hub had not yet taken place, and only three of the four proposed HIO startups in the SHIECAP application had achieved some level of operational status. Key characteristics of the three operational HIO startups, two of which provided evidence of a sustainable business model (HIO Stage 6), are summarized in Table 2. We briefly describe the three operational HIO startups below.

\section{Camden Coalition HIO}

The founding members of this HIO were part of the Camden Coalition of Healthcare Providers (CCHP), a group that began meeting informally in 2002 to discuss issues they faced and ways to leverage the members' health-related data. At the time of the SHIECAP funding announcement, an analysis of historical claims data from the city's three hospitals for patients in five U.S. zip codes had resulted in the identification of the emergency department "high utilizers," and the Coalition had received third-party grants to support outreach programs to provide alternative health care options.

The Camden Health Information Exchange was launched in 2010 by three CCHP hospitals, with one acting as the primary administrator, and by 2011 its outreach program was nationally recognized [23]. Initially a low-end HIE vendor solution with a centralized data warehouse architecture was implemented, and utilizing its SHIECAP grant 


\section{Sustainability Strategies for HIO Startups}

as a 501c3 (tax-exempt non-profit organization) it migrated to a more robust and user-friendly solution. With this new technology solution, all admissions to the city’s hospitals would be assessed for whether a patient should be enrolled in a Coalition program for additional care coordination support. The SHIECAP grant also enabled them to hire full-time staff to help them increase physician participation.

To cover the increased licensing fees and operational expenses, fees for the three founding hospitals were increased (see Table 2), but other members still paid no fees. By July 2013, the HIO was fully operational with a sustainable model.

Table 2. Characteristics of 3 New Jersey HIO Startups that Achieved Operational Status as of July 2013

\begin{tabular}{|c|c|c|c|}
\hline Characteristics & $\begin{array}{l}\text { Camden Coalition } \\
\text { (CCHP) }\end{array}$ & $\begin{array}{l}\text { Health-e-cITi } \\
\text { (HeC) }\end{array}$ & $\begin{array}{l}\text { Jersey Health Connect } \\
\text { (JHC) }\end{array}$ \\
\hline HIO Stage achieved ${ }^{1}$ & $\begin{array}{l}\text { Stage } 6 \\
\text { (fully operational with } \\
\text { sustainable business } \\
\text { model) }\end{array}$ & $\begin{array}{l}\text { Stage } 4 \\
\text { (pilot project or } \\
\text { implementation with } \\
\text { multiyear budget) }\end{array}$ & $\begin{array}{l}\text { Stages 6+ } \\
\text { (fully operational and } \\
\text { sustainable with } \\
\text { demonstration of expansion) }\end{array}$ \\
\hline $\begin{array}{l}\text { Governance structure } \\
\text { and administrative staff }\end{array}$ & $\begin{array}{l}\text { - HIE subcommittee } \\
\text { under Camden Coalition } \\
\text { - } 3 \text { HIO employees }\end{array}$ & $\begin{array}{l}\text { - Board of Trustees } \\
\text { - } 3 \text { subcommittees } \\
\text { - Liaison to Newark } \\
\text { Coalition } \\
\text { - } 3 \text { HIO employees }\end{array}$ & $\begin{array}{l}\text { - Part time Executive Director } \\
\text { - } 6 \text { subcommittees with new } \\
\text { members as non-voting } \\
\text { members } \\
\text { - Administrative HIO team of } \\
\text { contract staff with vendor } \\
\text { liaison }\end{array}$ \\
\hline HIE architecture & $\begin{array}{l}\text { Centralized } \\
\text { (data warehouse) }\end{array}$ & $\begin{array}{l}\text { Federated } \\
\text { (including edge servers at } \\
\text { hospitals) }\end{array}$ & $\begin{array}{l}\text { Hybrid } \\
\text { (central solution with } \\
\text { logically separated data) }\end{array}$ \\
\hline Implemented use cases & $\begin{array}{l}\text { - Lab results } \\
\text { - Radiology } \\
\text { - Physician portal } \\
\text { - Discharge } \\
\text { - Emergency department } \\
\text { (ED) notifications } \\
\text { - Analytics }\end{array}$ & $\begin{array}{l}\text { - Lab results } \\
\text { - Physician portal } \\
\text { - Discharge }\end{array}$ & $\begin{array}{l}\text { - Lab results } \\
\text { - Radiology } \\
\text { - Physician portal } \\
\text { - Secure messaging } \\
\text { - Patient portal }\end{array}$ \\
\hline $\begin{array}{l}\text { Connected physician } \\
\text { participants }\end{array}$ & $\begin{array}{l}100 \text { providers (viewing } \\
\text { and uploading) }\end{array}$ & $\begin{array}{l}\text { One large physician } \\
\text { practice, one FQHC (both } \\
\text { viewing) }\end{array}$ & $\begin{array}{l}1,800 \text { providers (viewing and } \\
\text { uploading) }\end{array}$ \\
\hline Annual member fees & $\begin{array}{l}\text { Administering hospital } \\
\$ 300 \mathrm{~K}(\$ 250 \mathrm{~K} \text { at outset) } \\
\text { Other } 2 \text { hospitals } \$ 75 \mathrm{~K} \\
(\$ 50 \mathrm{~K} \text { at outset) }\end{array}$ & $\begin{array}{l}\$ 25 \mathrm{~K} \text { per hospital to be } \\
\text { implemented after grant } \\
\text { period }\end{array}$ & $\begin{array}{l}\$ 100 \mathrm{~K} \text { per hospital, incl. } 50 \\
\text { licenses } \\
\$ 25 \mathrm{~K} \text { for additional } 50 \\
\text { licenses }\end{array}$ \\
\hline
\end{tabular}

\footnotetext{
${ }^{1}$ According to the stage model published by the e-Health Initiative [20]
} 


\section{Sustainability Strategies for HIO Startups}

\section{Health-e-cITi HIO}

The CEOs of eight Safety Net Charity hospitals in the Newark/Jersey City area had been collaborating since 2008 as Board members of the Greater Newark Health Care Coalition. All of these hospitals had large numbers of Medicaid patients and frequent ED users with substance abuse and behavioral health problems. The Coalition had received third-party grants to support their population health goals, and viewed the SHIECAP grants as an opportunity to electronically share patient information across their hospitals, FQHCs, and one large physician group.

$\mathrm{HeC}$ was the first of the NJ HIO startups to receive non-profit (501c3) status and gain access to its SHIECAP funding. At the time of the $\mathrm{HeC}$ grant proposal, a vendor partnership for the "alpha" development of a serviceoriented, federated HIE solution began under the leadership of a CIO champion. Each participating hospital absorbed the costs for maintaining and operating a local edge server. However, the initial no-fee model was to be replaced by a member fee model at the end of the SHIECAP grant cycle (see Table 2).

By July 2013, patient record queries from the hospital EDs were being piloted, and plans were underway for a nearby state university to develop EHR interfaces to on-board physician practices and provide other core HIE services.

\section{Jersey Health Connect HIO}

The SHIECAP grant was the catalyst for four suburban hospitals competing in north central NJ to collaborate on an HIO proposal. Two of these hospitals already had installed the same physician portal, and there was an early agreement that this vendor's technology would be utilized for sharing patient health information across HIO members. The HIO became incorporated as a non-profit under the name Jersey Health Connect (JHC) in February 2010. The annual fee for JHC member hospitals included up to 50 vendor licenses to connect with physician practices, and additional licenses were available at a discounted price.

The selected vendor solution was a hybrid: patient data from each member hospital is physically stored in a centralized repository maintained by the vendor, but kept logically separated. The operational exchange of patient data across member hospitals began in September 2012.Member hospitals in the process of implementing their own portals and private HIE capabilities could make their own decisions about the extent to use the HIO's platform and how to promote it among their employed and affiliated physicians. 


\section{Sustainability Strategies for HIO Startups}

By June 2013, 27 organizations (including 23 hospitals) were JHC members, covering a patient population of more than 4 million. HIO viewing access had been established with 1800 physicians using more than 40 different EMR systems, and its monthly transaction volume (>2.25 million) was reported to be the fourth largest in the U.S. [24]. Given the HIO's membership growth, financial sustainability with the initial fee structure was assured for at least the next two years.

\section{RESULTS}

\section{Common Startup Challenges}

Despite different geographic characteristics and HIE architectures, our cross-case data analyses revealed that each of the three operational HIO startups encountered common challenges in five key areas: Technology, Legal and policy work, Governance and administration, Hospital and physician participation, and Financial sustainability. We summarize these challenges in Table 3 and describe their impacts below.

Table 3. Common Startup Challenges Faced by NJ HIOs

\begin{tabular}{|l|l|}
\hline Key area & Challenges faced \\
\hline Technology & • Limited interoperability in newly certified EHR products \\
& - Lack of pre-existing standards and standards enforcement \\
& - Ongoing human intervention for patient record matching \\
\hline Legal and policy work & - High upfront costs to create cooperative member and vendor agreements \\
\hline $\begin{array}{l}\text { Governance and } \\
\text { administration }\end{array}$ & - Minimal government guidelines and mandates beyond HIPAA \\
\hline $\begin{array}{l}\text { Hospital and physician } \\
\text { participation }\end{array}$ & - - Compinimal or no full-time HIO employees as build initial governance structure \\
\hline Financial sustainability & - Physician buy-in for workflow redesign and EHR integration \\
\hline
\end{tabular}

Technology challenges at the time of the SHIECAP grant, including standards issues and interoperability, have previously been highlighted in U.S.-based reports [7, 13-16]. At CCHP, FQHCs required special interfaces due to enforced standards for these federally qualified entities; at $\mathrm{HeC}$, founding hospitals had to create or upgrade their 


\section{Sustainability Strategies for HIO Startups}

own EHR interfaces before being able to operate their own edge servers; at JHC, the lack of interoperability continued to impact the costs and speed of on-boarding physician practice EHRs. A key contributor to these interoperability challenges was the lack of pre-existing standards and standards enforcement at the federal and state levels. Although the NJ HIT Coordinator Office had facilitated the development of a security and privacy framework as part of its HIE Toolkit, usage was not mandated. Our interviewees reported that these technology challenges increased the startup costs and decreased the speed at which operational status was achieved. In addition, a widely known challenge was the human intervention required for patient record matching, despite sophisticated algorithms built into the different HIE solution.

In the absence of prior state-level efforts, costly legal and policy work was required to develop cooperative agreements with multiple organizational partners and vendors. Policy frameworks to comply with current federal and state regulations were a top priority, and mostly involved external contract work. Although all of the NJ HIO startups converged on an opt-out model for patient consent to comply with HIPAA, the records for urban patients in particular frequently contained state-defined sensitive data. "Grey” areas in government guidelines and guidance regarding the exchange of this data led to additional time delays and costs for legal counsel.

Governance and administration of the HIOs initially involved heavy reliance on in-kind contributions from founding members - including hospital CEOs and CIOs, their privacy \& security experts, and FQHC leaders- to coordinate across volunteer sub-committee members, contractors with specialized expertise, and HIE vendors. At the two largest startups, the initial HIO directors were full-time hospital CIOs. Several interviewees emphasized the need to build trust relationships across founding and non-founding members, including otherwise independent and/or competing healthcare providers.

Hospital and physician participation was a challenge due to competing priorities. Most founding members were in the process of implementing certified EHRs to achieve MU on a federal government timeline that coincided with the SHIECAP grant period. HIO participation by physicians also meant buy-in to workflow redesigns to include lookups to an external IT system. Other authors have highlighted similar physician-specific issues [25, 26].

Financial sustainability was the most frequently mentioned challenge, and this finding is consistent with prior studies based on data from other states [11, 13-16]. All of the HIO startups knew that the SHIECAP funding was for a fixed time period, and that hospital CEOs had to be convinced of the value of a regional initiative for which there 


\section{Sustainability Strategies for HIO Startups}

would be no federal grant renewal. An equitable member fee structure that would not overburden founding and nonfounding members was a concern of all three startups. Some state and HIO-level leaders had both jointly and independently approached one or more of the six largest payers in NJ with a cost/benefit case for participation, but by July 2013payerparticipationhad not been realized: aging legacy systems and the dynamic insurance industry environment were among the reasons cited.

As one of the HIO directors reflected:

"The governance is really hard to build, managing the grant money is really hard, getting the stakeholders to pay the money is really hard, the vendors are [hard to work with], the interfaces are hard to build. All this stuff is really hard."

\section{Two Sustainable HIO Startup Profiles}

Despite this challenging environment, two of the NJ HIO startups (CCHP and JHC) achieved a stage 6, operational status [20] by July 2013 with demonstrated financial sustainability beyond the initial grant period. Further, these two HIOs designed distinct models to ensure viability for continuing to operate in two very different regional contexts: 1) a population health mission for a defined inner-city area with an underserved patient population (CCHP), and 2) a healthcare transformation mission aligned with recent federal legislation for suburban hospitals competing in a much larger regional area $(\mathrm{JHC})$.

Based on our analyses, four interrelated characteristics distinguish these two HIO startup models: the primary patient populations and prior stakeholder relationships in their region, as well as their chosen technological architecture strategies and financial sustainability strategies. We summarize these characteristics and their implications in Table 4, and discuss each of these profiles below.

\section{CCHP: Urban HIO with Defined Population Health Area}

Camden's community-based coalition was initially formed to devise new ways to improve the health of an underserved urban patient population for a city in which nearly half of the population lived below the poverty line. Before the HITECH Act, "a bunch of grumpy primary care docs" met regularly to collaborate on solutions that could help bend the cost curves of the city's safety net hospitals that had "high utilizers" of their emergency departments (EDs). 
Table 4. Profiles of Two Sustainable HIO Startups

\begin{tabular}{|c|c|c|c|}
\hline $\begin{array}{l}\text { Key } \\
\text { characteristics }\end{array}$ & & $\begin{array}{l}\text { Urban HIO: } \\
\text { Defined area population health goals }\end{array}$ & $\begin{array}{l}\text { Suburban HIO: } \\
\text { Healthcare transformation goals }\end{array}$ \\
\hline \multirow[t]{2}{*}{$\begin{array}{l}\text { Primary patient } \\
\text { population }\end{array}$} & 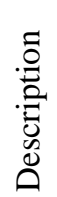 & $\begin{array}{l}\text { Underserved, less healthy urban population } \\
\text { with no insurance or Medicaid } \\
\text { Access to emergency department services } \\
\text { by safety net hospitals }\end{array}$ & $\begin{array}{l}\text { Healthier population with employer } \\
\text { health plans or Medicare } \\
\text { Access to multiple options for physician } \\
\text { and hospital services }\end{array}$ \\
\hline & 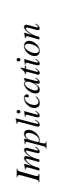 & $\begin{array}{l}\text { Providers with few slack resources for HIE } \\
\text { investments and greater incentives for } \\
\text { collaboration }\end{array}$ & $\begin{array}{l}\text { Providers with greater slack resources } \\
\text { and a focus on strategic IT investments }\end{array}$ \\
\hline \multirow[t]{2}{*}{$\begin{array}{l}\text { Prior stakeholder } \\
\text { relationships }\end{array}$} & 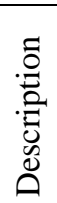 & $\begin{array}{l}\text { Members of community coalitions to } \\
\text { address population health issues } \\
\text { Members of clinically-related professional } \\
\text { associations to seek } 3^{\text {rd }} \text {-party funding }\end{array}$ & $\begin{array}{l}\text { Members of business-related } \\
\text { professional organizations } \\
\text { Organizational and joint negotiating } \\
\text { power with vendors }\end{array}$ \\
\hline & 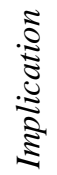 & $\begin{array}{l}\text { Faster formation of HIO startups due to } \\
\text { pre-existing collaborative and trusting } \\
\text { relationships for achieving common vision }\end{array}$ & $\begin{array}{l}\text { Quicker selection of HIE vendor } \\
\text { solution that involves less integration }\end{array}$ \\
\hline \multirow[t]{2}{*}{$\begin{array}{l}\text { Technological } \\
\text { architecture } \\
\text { strategy }\end{array}$} & ๑ే: & $\begin{array}{l}\text { Centralized: Data replication in central } \\
\text { repository }\end{array}$ & $\begin{array}{l}\text { Hybrid: Physically centralized, logically } \\
\text { federated }\end{array}$ \\
\hline & 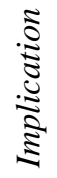 & Enables better analytics opportunities & $\begin{array}{l}\text { More complex for analytics, but data } \\
\text { privacy advantages }\end{array}$ \\
\hline \multirow[t]{2}{*}{$\begin{array}{l}\text { Sustainability } \\
\text { strategy }\end{array}$} & 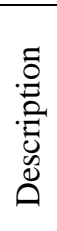 & $\begin{array}{l}\text { Focus first on initially defined geographical } \\
\text { area and mission of collaborative members } \\
\text { Keep HIE investments and staffing at low } \\
\text { levels }\end{array}$ & $\begin{array}{l}\text { Rely on partnership with mature vendor } \\
\text { to expand regional coverage } \\
\text { Invest in standard interfaces to reduce } \\
\text { initial costs for targeted new hospitals } \\
\text { and physician practices }\end{array}$ \\
\hline & 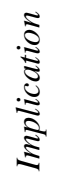 & $\begin{array}{l}\text { Slow growth in HIO coverage, but financial } \\
\text { viability with low-cost operations and } \\
\text { external funding for core mission }\end{array}$ & $\begin{array}{l}\text { High growth in HIO coverage, with } \\
\text { financial viability due to economies of } \\
\text { scale and scope }\end{array}$ \\
\hline
\end{tabular}




\section{Sustainability Strategies for HIO Startups}

These clinical professionals not only shared common population health goals, but also a vision about the role of patient information sharing to these issues. Through their pre-HITECH collaborations, the founding members of the $\mathrm{HIO}$ and other practitioners in the community already had established stakeholder relationships built on a network of trust that helped them "get through the hard stuff" of designing new outreach solutions.

After receiving SHIECAP funding as a 501c3 entity, the HIO invested in a centralized technological architecture with a robust "warehouse" suitable for data analytics: once HIO members' transactions (e.g., patient admission, discharge) are pushed into the repository, they are instantly available for querying and sharing.

However, for this urban HIO a conservative sustainability strategy with clear hospital commitments, but not too onerous membership fees was still considered the best fit: a stable member base of sufficient size would first be established for a well-defined geography before other hospitals could become members. The targets for physician provider growth were also conservative and initially focused on physician viewing access only.

By maintaining their focus on population health goals for a defined underserved population, and "just being a turtle," CCHP will be able to continue to utilize third-party grants to fund HIO activities in support of their core mission.

\section{JHC: Suburban HIO with Healthcare Transformation Goals}

In contrast, JHC's primarily suburban patient population had multiple options for healthcare services that were covered by employer insurance plans or Medicare. Many of the physicians in the private practices that performed these services were also affiliated with more than one hospital system in JHC's geographic region.

The formation of this suburban HIO was primarily enabled by CIOs who had prior working relationships as part of an active professional association within the state. Several interviewees mentioned the lack of "egos" and high trust among these IT leaders. They also shared a common desire to leverage the SHIECAP program and other HITECH funding to align their hospitals with a new healthcare landscape that would reward patient care coordination across hospital and physician providers.

Two of the founding members had already implemented an exchange solution by a vendor that was performing well in an increasingly dynamic technology environment. To avoid a major IT infrastructure investment, the HIO 


\section{Sustainability Strategies for HIO Startups}

founders decided to also leverage these pre-existing relationships with a common vendor to negotiate a partnership with the HIO.

This technological architecture strategy required minimal IT investments by not only its founding members, but also

its future members. The selected vendor's scalable HIE technology also had data privacy advantages: each HIO member's data is physically centralized in a repository maintained by the vendor, but in logically separated silos.

JHC's progressive sustainability strategy is based on its partnership with a mature vendor hosting that can support membership growth. Starting with a modest per-hospital membership fee, more attractive HIE vendor discounts and licenses for smaller providers can be offered to old and new members as the number of member hospitals increases.

By funding the vendor's development of standard interfaces, the HIO also could have a faster and cheaper on-

Table 5. Selected Quotations for Key Characteristics of Two HIO Startup Models

\begin{tabular}{|c|c|c|}
\hline $\begin{array}{l}\text { Key } \\
\text { characteristics }\end{array}$ & $\begin{array}{l}\text { Urban HIO: } \\
\text { Defined area population health goals }\end{array}$ & $\begin{array}{l}\text { Suburban HIO: } \\
\text { Healthcare transformation goals }\end{array}$ \\
\hline & \multicolumn{2}{|c|}{$\begin{array}{l}\text { "I really do believe the urban model is different than the suburban model. In the urban area, } \\
\text { inner-city hospitals see so much more behavioral health and substance abuse. And not that the } \\
\text { suburban areas don't see it, but they are the high urban utilizers. I do think there are different } \\
\text { models for inner cities and we should stay focused on that." - State Administrator }\end{array}$} \\
\hline $\begin{array}{l}\text { Primary patient } \\
\text { population }\end{array}$ & $\begin{array}{l}5 \text { zip codes in } 1 \text { county with dense, urban } \\
\text { population area }\end{array}$ & $\begin{array}{l}10 \text { counties with less dense, largely suburban } \\
\text { population area }\end{array}$ \\
\hline $\begin{array}{l}\text { Prior stakeholder } \\
\text { relationships }\end{array}$ & $\begin{array}{l}\text { "It was a bunch of grumpy primary care docs } \\
\text { [meeting regularly]. And then it eventually } \\
\text { formed up into an organization, and eventually } \\
\text { did a lot of learning and collaborative work. } \\
\text {...What I have come to realize is that an HIE is } \\
\text { not an IT system: it is a network of trust and } \\
\text { relationships. And if you put the relationships } \\
\text { and the trust first, and then you put the idea out } \\
\text { of what you can do with that trust, then you can } \\
\text { get through the hard stuff." - HIO director }\end{array}$ & $\begin{array}{l}\text { "There are [CIOs from] hospitals that are } \\
\text { very competitive with each other. But I've } \\
\text { never ever felt for one minute that there was } \\
\text { any competitive nature in that room. There } \\
\text { are no egos and I am very comfortable with } \\
\text { the fact that we are all there for the right } \\
\text { reason and that's for the good of the patient." } \\
\text { - Hospital CIO }\end{array}$ \\
\hline $\begin{array}{l}\text { Technological } \\
\text { architecture } \\
\text { strategy }\end{array}$ & $\begin{array}{l}\text { "We are still using warehouse model, edge } \\
\text { server model is too expensive and too } \\
\text { complicated. It's much more fun to warehouse it } \\
\text { so you can play with the data. ... There is a } \\
\text { decision support component in the HIE. ... In } \\
\text { addition to that we also have reporting and data } \\
\text { analytical tools that are in there." - HIO director }\end{array}$ & $\begin{array}{l}\text { "JHC decided not to put any money in that } \\
\text { infrastructure and really use a software-as-a- } \\
\text { service model. Especially when you look at } \\
\text { some of the security and the privacy aspects } \\
\text { that are part of that, you really want to make } \\
\text { sure that you attach yourself to something } \\
\text { that has that built in within their particular } \\
\text { infrastructure." - HIO director }\end{array}$ \\
\hline $\begin{array}{l}\text { Sustainability } \\
\text { strategy }\end{array}$ & $\begin{array}{l}\text { "This is all about just being a turtle. We were in } \\
\text { the black the first day we turned on, because we } \\
\text { had very low cost infrastructure, we started very } \\
\text { small, we didn't do a lot of hiring. So [the HIO } \\
\text { is] just going to keep creeping along and } \\
\text { creeping along." - HIO director }\end{array}$ & $\begin{array}{l}\text { "Growth is really a great sustainer. The more } \\
\text { hospitals and organizations that you have } \\
\text { join, the more funding you will receive." - } \\
\text { HIO manager }\end{array}$ \\
\hline
\end{tabular}




\section{Sustainability Strategies for HIO Startups}

boarding process for physician practices and other smaller providers. This progressive growth has become a "great sustainer" beyond the SHIECAP grant period.

Selected quotations from our interview data in support of the differences between these two HIO startup models are provided in Table 5 .

\section{CONCLUSIONS}

Key to the timely formation of the HIO startups was the ability to leverage pre-existing stakeholder relationships. The technology and non-technology challenges faced by all of NJ HIOs influenced their timelines to become operational and their startup costs, but prior relationships with other founding members enabled them to initially rely on in-kind contributions for HIO governance and administration. These pre-existing relationships also enabled the founding members to initially avoid devoting a lot of upfront time and effort to achieving broader stakeholder engagement —including payers [27]—-beyond these pre-existing “communities."

However, our cross-case analyses also revealed that the HIO startup funding provided by the federal SHIECAP grant was a catalyst, but not a sufficient condition, to develop a sustainable financial and operational HIO model within the fixed three-year grant period. The sustainable urban HIO (CCHP) leveraged its focus on population health for an under-served patient community, which enabled it to continue to attract third-party funding to support its conservative growth strategy with a technology investment in a warehouse model with data analytic tools. The suburban HIO (JHC) pursued a different sustainability approach: by leveraging not only pre-existing relationships among its hospital CIOs but also a relationship with a mature vendor partner, it was able to pursue an aggressive growth strategy with a technological architecture that was an attractive investment for new members. This membership growth, in turn, ensured financial sustainability for this HIO beyond the initial grant period.

In contrast, the founding members of the third NJ HIO that became operational (HeC) chose a federated technological architecture. Although pre-existing relationships among its founding members enabled a commitment to a technology strategy that required both initial and ongoing IT and process investments by each HIO member, this federated architecture approach proved to be a barrier to moving beyond a pilot stage and demonstrating financial and operational sustainability for an HIO to serve an urban patient population. Thus, our study of bottom-up HIO 


\section{Sustainability Strategies for HIO Startups}

initiatives in New Jersey provides strong evidence for the necessity of a fit between the HIO's technology and sustainability strategies and its specific regional context.

On the other hand, we recognize that the generalizability of our study is limited. First, the state of New Jersey, in which these three HIO startups were studied, had very limited HIE activities prior to the SHIECAP grant and did not develop a state-wide capability by the time of our data collection. Second, unlike many other states in the U.S., New Jersey had no geographic regions classified as rural. Thus, our findings are based on operational HIO startups for urban versus suburban U.S. patient populations only. Our observed fit criteria may therefore not be generalizable to other U.S. states or national contexts in which HIEs have additional funding sources and different regional contexts. Although our HIO findings need to be applied with caution, our study clearly demonstrates how relatively low levels of government funding for a fixed multi-year period can result in a significant increase in bottom-up HIE capabilities with the potential for sustainability. The notion that HIE technologies and growth strategies must fit the needs of regional populations also holds relevant policy implications for national healthcare systems within and outside the U.S., especially those that have been challenged by top-down implementations of HIE capabilities. Our findings therefore also suggest that more field research with sampling approaches that reflect regional context differences at the $\mathrm{HIO}$ level—including both pre-existing patient populations and stakeholder characteristics—is needed to better understand the effectiveness of HIE policy levers and government funding mechanisms.

\section{ACKNOWLEDGEMENTS}

The authors gratefully acknowledge the participation of all of the interviewees who shared their experiences and insights for this study.

\section{ETHICAL APPROVAL}

The Institutional Review Board of Stevens Institute of Technology approved the study protocol.

\section{FUNDING}

None. 


\section{COMPETING INTERESTS}

None declared.

\section{REFERENCES}

1. Sheikh A, Sood HS, Bates DW. Leveraging health information technology to achieve the "triple aim" of healthcare reform. Journal of the American Medical Informatics Association (JAMIA). 2015;22(4):849-56.

2. Kuperman GJ. Health-information exchange: why are we doing it, and what are we doing? Journal of the American Medical Informatics Association (JAMIA). 2011;18(5):678-82.

3. Jha A, Doolan D, Grandt D, Scott T, Bates D. The use of health information technology in seven nations. International Journal of Medical Informatics. 2008;77(12):848-54.

4. Deutsch E, Duftschmid G, Dorda W. Critical areas of national electronic health record programs-Is our focus correct? International Journal of Medical Informatics. 2010;79(3):211-22.

5. Vest JR, Gamm LD. Health information exchange: persistent challenges and new strategies. Journal of the American Medical Informatics Association (JAMIA). 2010;17(3):288-94.

6. Adler-Milstein J, McAfee AP, Bates DW, Jha AK. The state of regional health information organizations: current activities and financing. Health Affairs. 2008;27(1):60-9.

7. Edwards A, Hollin I, Barry J, Kachnowski S. Barriers to cross-institutional health information exchange: a literature review. Journal of Healthcare Information Management (JHIM). 2010;24(3):22-34.

8. Adler-Milstein J, Landefeld J, Jha AK. Characteristics associated with Regional Health Information Organization viability. Journal of the American Medical Informatics Association (JAMIA). 2010;17(1):61-5.

9. Vest JR, Campion TR, Jr., Kern LM, Kaushal R. Public and private sector roles in health information technology policy: Insights from the implementation and operation of exchange efforts in the United States. Health Policy and Technology. 2014;3(2):149-56.

10. HIMSS. HIE HITECH ARRA Fact Sheet: Health Information Management Systems Society (HIMSS); 2010 [2015/7/8]. Available from: http://www.himss.org/files/HIMSSorg/content/files/12 04 09_ARRAHITECHHIE FactSheet.pdf.

11. Adler-Milstein J, Bates DW, Jha AK. Operational Health Information Exchanges Show Substantial Growth, But Long-Term Funding Remains A Concern. Health Affairs. 2013;32(8):1486-92.

12. Lenert L, Sundwall D, Lenert ME. Shifts in the architecture of the Nationwide Health Information Network. Journal of the American Medical Informatics Association (JAMIA). 2012;19(4):498-502.

13. Dullabh P, Adler-Milstein J, Hovey L, Jha AK. Final Report: Key Challenges to Enabling Health Information Exchange and How States Can Help. Bethesda, MD: NORC at the University of Chicago 2014.

14. Dullabh P, Adler-Milstein J, Nye C, Moiduddin A, Virost LM, Babalola E, et al. Evaluation of the State Health Information Exchange Cooperative Agreement Program: Early Findings from a Review of Twenty-Seven States. Case Study/Report. Bethesda, MD: NORC at the University of Chicago 2012.

15. Dullabh P, Hovey L, Ubri P. Evaluation of the State Health Information Exchange Cooperative Agreement Program: Case Study Synthesis: Experiences from Five States in Enabling HIE. Bethesda, MD: NORC at the University of Chicago 2013.

16. Dullabh P, Ubri P, Hovey L. The State HIE Program Four Years Later: Key Findings on Grantees' Experiences from a Six-State Review. Case Study Report. Bethesda, MD: NORC at the University of Chicago 2014.

17. Kern LM, Wilcox AB, Shapiro J, Yoon-Flannery K, Abramson E, Barron Y, et al. Community-based health information technology alliances: potential predictors of early sustainability. The American journal of managed care. 2011;17(4):290-5.

18. Yin RK. Case study research: Design and methods: Sage publications; 2013.

19. Corbin J, Strauss A. Grounded Theory Research - Procedures, Canons and Evaluative Criteria. Qualitative Sociology. 1990;13(1):3-21.

20. eHealth Initiative. The State of Health Information Exchange in 2010: Connecting the Nation to Achieve Meaningful Use. Washington, DC: eHealth Initiative, 2010.

21. ONC. State HIE Strategic and Operational Plan Emerging Models. Office of the National Coordinator for Health Information Technology (ONC), Department of Health and Human Services 2011. 


\section{Sustainability Strategies for HIO Startups}

22. Dullabh P, Adler-Milstein J, Nye C, Moiduddin A, Virost LM, Babalola E, et al. Evaluations of the State Health Information Exchange Cooperative Agreement Program. Case Study/Report. NORC at the University of Chicago 2011-2014.

23. Gawande A. The hot spotters: can we lower medical costs by giving the neediest patients better care? The New Yorker. 2011(January):40-51.

24. Tripathi M. Current State of HIE. Massachusetts eHealth Collaborative 2013.

25. Hincapie AL, Warholak TL, Murcko AC, Slack M, Malone DC. Physicians' opinions of a health information exchange. Journal of the American Medical Informatics Association (JAMIA). 2011;18(1):60-5.

26. Unertl KM, Johnson KB, Lorenzi NM. Health information exchange technology on the front lines of healthcare: workflow factors and patterns of use. Journal of the American Medical Informatics Association (JAMIA). 2012;19(3):392-400.

27. Cross DA, Lin SC, Adler-Milstein J. Assessing payer perspectives on health information exchange. Journal of the American Medical Informatics Association (JAMIA). 2015. 